\title{
PENGARUH KOMPENSASI DAN LINGKUNGAN KERJA TERHADAP KEPUASAN KERJA KARYAWAN PADA PT.FAMILI RAYA PADANG
}

\author{
Riki Ricardo, DR. H. Agussalim. M, SE, MS, Nova Begawati, SE.MM \\ Jurusan Manajemen \\ Fakultas Ekonomi \\ Universitas Ekasakti Padang
}

\begin{abstract}
Service has a very important role in everyday life in the environment. But as individuals who have desires and expectations, should get good attention from service providers. This is done to improve service as the main goal in government or non government. This study aims to determine the Influence of Bulog Rice Distribution Service to Community Satisfaction in Kenagaarian Koto Tuo, Sijunjung. Where independent variable is bulog rice distribution service and community satisfaction as dependent variable. Population in this research is all recipients of bulog rice in kenagarian koto tuo 2017 that is 85 people. Samples taken are all people who received bulog rice in kenagian koto tuo in 2017 as many as 85 respondents. Data were collected by using survey method through questionnaires filled by community receiving bulog rice. Then the data obtained were analyzed by using simple linear regression analysis. This analysis includes Test Validity, Reliability Test, Classic Assumption Test, Simple Linear Regression Analysis, Hypothesis Test with $t$ test, and Determination Coefficient analysis (R2). Based on the research results obtained regression equation $Y=-8,120+0.938 X$. Based on statistical data analysis, the indicators in this study are valid and the variable is reliable. Individually, the variable that has a greater influence is the variable quality of Satisfaction with regression coefficient of 0.938. hypothesis testing using $t$ test shows that the independent variables studied proved to positively affect the dependent variable. The value of $t$ arithmetic in this study seen that $t$ arithmetic for $t$ arithmetic $>t$ table that is 47.793> 1.9883. with a significance level of $0.000<\alpha=0.05$ this means variables have $a$ positive and significant effect. The result of determination coefficient test $\left(R^{2}\right)$ shows Adjusted $R$ Square 0,959 or 95,9\% mean variation of individual impact variable can be explained by service variable whereas 0,41 or $4,1 \%$ is explained by other variabl
\end{abstract}

Keywords: service, satisfaction, rice, bulog.

\section{PENDAHULUAN}

Pada era globalisasi sekarang dan masa-masa yang akan datang kompetisi yang terjadi bersifat global dan adanya perubahan-perubahan kondisi ekonomi menyebabkan banyak organisasi dari bermacammacam ukuran melakukan langkah restrukturisasi. Hal ini mendorong terjadinya perubahan paradigma organisasi dari tradisional menjadi moderen. Kondisi ini harus benarbenar disadari dan dipersiapkan secara profesional. Terutama pada faktor-faktor sumber daya
manusia(SDM) yang bermutu dengan kualifikasi yang sesuai. Oleh karena itu, meningkatkan kepuasan kerja karyawan merupakan hal yang sangat penting didalam usaha agar produktifitas dan kinerja perusahaan menjadi efektif sesuai dengan tujuan yang telah ditetapkan, Sehingga perlu upaya secara terus-menerus dan berkesinambungan. Untuk menentukan hal ini perlu dicari faktor-faktor yang mempengaruhi Kepuasan kerja.

Meningkatkan kepuasan kerja karyawan menjadi tantangan sumber 
daya manusia (MSDM), karena keberhasilan dalam mencapai tujuan dan keberlangsungan hidup perusahaan bergantung pada kualitas sumber daya manusia (SDM). Kepuasan kerja merupakan sikap atau perasaan karyawan terhadap aspek-aspek yang menyenangkan atau tidak menyenangkan mengenai perkerjaan yang sesuai dengan penilaian masing-masing pekerja Badriyah,M. (2015 : 8).

Menurut Bejo Siswanto Sastrohadiwiryo dalam bukunya Yuniarsih (2011:5) Kompensasi adalah imbalan atas jasa atau balas jasa yang diberikan oleh perusahaan kepada tenaga kerja , karena para tenaga kerja tersebut telah memberikan sumbangan tenaga dan pikiran demi kemajuan perusahaan guna mencapai tujuan yang ditetapkan.Apabila kompensasi yang diberikan perusahaan tidak tepat, perusahaan bisa kehilangan karyawan yang memiliki kinerja baik, dan perusahaan harus mengeluarkan biaya lagi untuk penarikan karyawan baru atau yang biasa yang disebut dengan istilah recruitment. Akan ada dua kemungkinan yang muncul dari recrutment ini. Pertama, perusahaan berhasil mendapatkan karyawan yang berkompeten, kedua perusahaan justru gagal untuk mendapatkan karyawan yang berkompeten seperti yang diharapkan. Jika kemungkinan kedua yang muncul, maka sudah dipastikan perusahaan akan mengalami kerugiaan karena tidak dapat berkompetisi di bidang SDM dengan kompetitor. Sebaliknya, Jika program kompensasi dirasa cukup adil dan kompetitif, maka perusahaan akan lebih mudah mendapatkan karyawan yang pontensial.

PT. Famili Raya Padang adalah industri yang bergerak dibidang produksi karet remah (Crumb Rubber ), menggunakan bahan baku yang berasal dari petani karet yang tersebar di beberapa kabupaten dan diterima di gerbang pabrik dalam bentuk Bahan Olah Karet Rakyat (BOKAR). sebagai suatu organisasi yang bergerak dibidang produksi karet remah (Crumb Rubber ), menginginkan perusahaannya dapat memaksimalkan dalam mendapatkan laba. Tentunya laba tersebut tergantung pada kinerja para karyawan. Karena dengan adanya kinerja yang optimal, menunjukan terpenuhinya standar kerja yang ditetapkan perusahaan. Namun demikian kinerja karyawan tidak selalu sesuai dengan harapan perusahaan. Dari penilaian kinerja terdapat masih adanya kurang optimalisasi kinerja kayawan sehingga diturunkannya rencana kerja perusahaan.

Selain itu lingkungan kerja juga akan mempengaruhi tingkat produktivitas kinerja karyawan karena dengan lingkungan yang baik karyawan akan nyaman dalam berkerja. Namun fakta yang penulis temukan dilapangan bahwa masih kurangnya perhatiaan perusahaan terhadap kenyamanan karyawan dalam berkerja seperti masih kurangnya sirkulasi udara, pencahayaan dan dekorasi ruangan kerja karyawan.

Berdasarkan latar belakang tersebut, maka penulis melakukan penelitian lebih lanjut dengan judul'Pengaruh Kompensasi dan Lingkungan Kerja Terhadap 
Kepuasan Kinerja Karyawan Pada PT. Famili Raya Padang”

\section{Perumusan Masalah}

Berdasarkan masalah-masalah yang sudah diuraikan sebelumnya, maka permasalahan dalam penelitian dapat dirumuskan sebagai berikut: Apakah kompensasi dan lingkungan kerja berpengaruh terhadap kepuasan kerja karyawan pada PT.Famili Raya Padang, baik secara parsial maupun simultan.

\section{TINJAUAN PUSTAKA}

\section{Kompensasi}

Kompensasi adalah Imbalan atau balas jasa yang diberikan perusahaan kepada tenaga kerja, karena para tenaga kerja tersebut telah memberikan sumbangan tenaga dan pikiran mereka demi kemajuan perusahaan guna mencapai tujuan yang ditetapkan (Bejo Siswanto Sastrohadiwiryo,(2011:12).

Kompensasi dibedakan menajdi dua, yaitu : Kompensasi langsung yaitu berupa gaji, upah dan insetif ; dan Kompensasi tidak langsung berupa asuransi, tunjangan, cuti, penghargaan.

\section{Lingkungan Kerja}

Menurut Robins (2010:75)

Lingkungan kerja adalah keadaan atau situasi yang berpotensi mempengaruhi kinerja organisasi yang ada didalamnya. lingkungan dirumuskan menjadi dua yaitu lingkungan umum dan lingkungan khusus. Lingkungan umum adalah segala sesuatu diluar organisasi yang memiliki potensi untuk mempengaruhi organisasi. Lingkungan Khusus adalah bagian lingkungan yang secara langsung berkaitan dengan pencapaian sasaran-sasaran sebuah organisasi.

Menurut Sunyoto, D. (2012:43) Lingkungan kerja adalah segala sesuatu yang ada disekitar para pekerja dan yang dapat mempengaruhi dirinya dalam menjalankan tugas-tugas yang dibebankan, misalnya kebersihan, musik, penerangan dan lain-lain. Sedangkan Menurut (Nitisemito, 2010:34) Lingkungan Kerja adalah segala sesuatu yang ada disekitar karyawan dan dapat mempengaruhi dalam menjalankan tugas yang diembankan kepadanya misalnya dengan adanya air conditioner $(A C)$, penerengan yang memadai dan sebagiannya.

\section{Kepuasan Kerja}

Menurut Kreitner dan Kinicki (2014:52) kepuasan kerja adalah "suatu efektifitas atau respons emosional terhadap berbagai aspek pekerjaan". Menurut Edy Sutrisno (2010:72) Kepuasan gan situasi kerja, kerja sama karyawan, imbalan yang diterima dalam kerja, dan halhal yang menyangkut faktof fisik dan psikologis. Menurut Robbins (2010:25) kepuasan kerja adalah "sikap umum terhadap pekerjaan seseorang yang menunjukkan perbedaan antara jumlah penghargaan yang diterima pekerja dan jumlah yang mereka yakini seharusnya terima.

\section{Pengembangan Hipotesis}


Berdasarkan rumusan masalah Tinjauan Pustaka yang penulis kemukakan diatas, maka dapat hipotesis dikemukakan sebagai berikut :

Diduga bahwa kompensasi dan lingkungan kerja berpengaruh signifikan terhadap kinerja karyawan PT. Famili Raya Padang.

\section{Metode Penelitian}

\section{Populasi dan Sampel}

Populasi adalah suatu kelompok yang terdiri dari objek atau subjek yang mempunyai kualitas dan karakteristik tertentu yang ditetapkan oleh peneliti untuk dipelajari dan kemudian ditarik kesimpulan (Sugiyono,2014:45). Sedangkan menurut Arikunto (2010:70) penentuan sampel apabila kurang dari 100 lebih baik diambil semua hingga penelitiannya merupakan penelitiaan populasi. Populasi dalam penelitian ini adalah Seluruh Karyawan PT.Famili Raya Padang yang berjumlah 45 orang.

Sampel merupakan bagian dari populasi yang ingin diteliti oleh peneliti. Menurut Sugiyono (2014), sampel adalah bagian dari jumlah dan karakteristik yang dimiliki tersebut. Sehingga sampel merupakan bagian dari populasi yang ada. Sampel pada penelitian ini menggunakan metode Sampling Jenuh. Sampling Jenuh adalah teknik penentuan sampel semua anggota populasi digunakan sebagai sampel (Sugiyono,2014 :48).Jadi Penulis menjadikan sampel dalam penelitaian ini adalah 45 orang yang ada di PT.Famili Raya Padang.

\section{Defenisi Operasional Variabel}

Variabel penelitian dalam penelitian ini diklasifikasikan menjadi dua yaitu variabel indenpenden (bebas) dan variabel dependen (terikat). Penelitian ini mempunyai dua variabel indenpenden ( bebas) dan satu variabel dependen (terikat).

Kompensasi dan Lingkungan Kerja variabel indenpenden (bebas) dan Kepuasan Kerja variabel dependen (terikat).

\section{Kompensasi}

Kompensasi adalah Imbalan atau balas jasa yang diberikan perusahaan kepada tenaga kerja, karena para tenaga kerja tersebut telah memberikan sumbangan tenaga dan pikiran mereka demi kemajuan perusahaan guna mencapai tujuan yang ditetapkan (Bejo Siswanto Sastrohadiwiryo,(2011:12).

\section{Lingkungan Kerja}

Menurut Robins (2010:75) Lingkungan kerja adalah keadaan atau situasi yang berpotensi mempengaruhi kinerja organisasi yang ada didalamnya. lingkungan dirumuskan menjadi dua yaitu lingkungan umum dan lingkungan khusus. Lingkungan umum adalah segala sesuatu diluar organisasi yang memiliki potensi untuk mempengaruhi organisasi. Lingkungan Khusus adalah bagian lingkungan yang secara langsung berkaitan dengan pencapaian sasaran-sasaran sebuah organisasi.

\section{Kepuasan Kerja}

Menurut Edy Sutrisno (2010:72) Kepuasan gan situasi kerja, kerja sama karyawan, imbalan yangditerima dalam kerja, dan hal- 
hal yang menyangkut faktof fisik dan psikologis.

\section{Metode Analisis \\ Analisis Regresi Berganda}

Model analisis yang dipakai dalam penelitian ini adalah model analisis regresi berganda. Regresi berganda digunakan untuk mengetahui hubungan antara dua atau lebih variabel independen (X1 dan X2) dengan variabel dependen (Y). Model regresi yang digunakan.

\section{$\mathrm{Y}=\mathrm{a}+\mathrm{b} 1 \mathrm{X} 1+$ b2X2+ei}

Dimana :

$$
\begin{aligned}
\mathrm{Y} & =\text { Kepuasan Kerja } \\
\mathrm{X} 1 \quad= & \text { Kompensasi } \\
\mathrm{X} 2 & =\text { Lingkungan Kerja } \\
\mathrm{a} & =\text { Konstanta regresi } \\
& \text { b1,2 =Angka koefisien } \\
& \text { regresi yang menunjukan } \\
& \text { pengaruh variabel } \\
& \text { dependen yang didasarkan } \\
& \text { pada hubungan nilai } \\
& \text { variabel independen }
\end{aligned}
$$

\section{Uji Analisis Data}

\section{Uji Validitas}

Menurut Sutrisno Hadi (2016:53) uji validitas dilakukan untuk mengungkapkan apakah pertanyaan pada kuisioner tersebut valid atau tidak.

\section{Uji Reliabilitas}

Reliabilitas adalah tingkat kestabilan suatu alat ukur dalam mengukur suatu gejala. Menurut Sutrisno Hadi dalam Bawono (2016:23) menyatakan bahwa reliabilitas menunjukan sejauh mana suatu hasil pengukuran relatif konsisten atau tidak berbeda jika diukur ulang pada subyek yang sama.

\section{Uji Asumsi Klasik}

Dilakukan untuk memberikan kepastian bahwa persamaan regresi yang didapatkan memiliki ketepatan dalam estimasi tidak biasa dan konsisten. Dalam penelitian ini uji asumsi klasik yang digunakan adalah:

\section{Uji Normalitas}

Uji Normalitas digunakan untuk menguji apakah nilai residual yang dihasilkan dari regresi terdistribusi secara normal atau tidak. Model regresi yang baik adalah yang memiliki nilai residual yang terdistribusi secara normal (Agussalim, 2015:32).

\section{Uji multikolinieritas}

Uji multikolinieritas digunakan untuk menguji apakah didalam model regresi ditemukan ada atau tidaknya korelasi antara variabel bebas. Jika terjadi korelasi maka dinamakan terdapat problem multikolinieritas. Model regresi yang baik seharusnya tidak terjadi korelasi diantara variabel independen, jika terbukti ada multikolinieritas seharusnya salah satu independen yang ada dikeluarkan dari model, lalau pembuatan model regresi diulang kembali (Singgih Santoso, 2012:90).

\section{Uji heteroskedastisitas}

Uji heteroskedastisitas bertujuan untuk menguji apakah dalam sebuah model regresi, terjadi ketidaksamaan varians atau residual dari satu pengamatan ke pengamatan yang lain. Menurut Gujarati (2012:406) untuk menguji ada tidaknya heteroskedastisitas digunakan uji- 
rank Spearman yaitu dengan mengkorelasikan variabel independen terhadap nilai absolut dari residual (error).

\section{Pengujian Hipotesis}

Alat analisis yang digunakan dalam penelitian ini adalah dengan uji statistik yaitu uji t dan uji F.

Uji t (uji parsial)

Uji t pada dasarnya menunjukkan seberapa jauh pengaruh variabel independen terhadap variabel dependen dengan menganggap variabel independen lainnya konstan (Ghozali, 2011)

Uji F (uji secara simultan)

Uji $\mathrm{F}$ pada dasarnya menunjukkan apakah semua variabel independen atau bebas yang dimasukkan dalam model mempunyai pengaruh secara bersama-sama terhadap variabel dependen (Sugiyono, 2015).

\section{HASIL PENELITIAN DAN PEMBAHASAN}

Pada penelitian ini peneliti meneliti dua variabel indenpenden (Kompensasi dan Lingkungan Kerja) Apakah berpengaruh terhadap variabel dependen ( Kepuasan Kerja). Secara sattistik dilakukan dengan pengujiaansecara parsial dan simultan dengan model regresi berganda dengan menggunakan software SPSS 20.

\section{Uji Reliabilitas}

Hasil uji reliabilitas dapat dilihat pada tabel berikut ini :

\section{Tabel Uji Reliabilitas}

\begin{tabular}{|l|l|l|l|}
\hline $\begin{array}{l}\text { Variab } \\
\text { el }\end{array}$ & $\begin{array}{l}\text { Nilai } \\
\text { cronba } \\
\text { ch }\end{array}$ & $\begin{array}{l}\text { Ite } \\
\mathrm{m}\end{array}$ & $\begin{array}{l}\text { Keterang } \\
\text { an }\end{array}$ \\
\hline
\end{tabular}

\begin{tabular}{|c|c|c|c|}
\hline & alpha & & \\
\hline $\mathrm{X} 1$ & 0,717 & 16 & $\begin{array}{ll}0,6 & > \\
0.717 & \\
\text { dari } & 16 \\
\text { item } & \end{array}$ \\
\hline $\mathrm{X} 2$ & 0,713 & 26 & $\begin{array}{ll}0,6 & > \\
0.713 & \\
\text { dari } & 26 \\
\text { item } & \end{array}$ \\
\hline $\mathrm{Y}$ & 0,743 & 21 & $\begin{array}{ll}0,6 & \\
0.743 & \\
\text { dari } & 21 \\
\text { item } & \\
\end{array}$ \\
\hline
\end{tabular}

Dari penyajian table 4.10 diatas, maka seluruh variabel penelitian dinyatakan reliabel, dimana hasil perhitungan uji reliabilitas yang masing masing variabelnya menunjukan Cronbach's Alpha lebih besar dari 0,6. Hal ini berarti keseluruhan variabel dapat digunakan untuk pengolahan data lebih lanjut.

\section{Uji Asumsi Klasik}

\section{Uji Normalitas}

Bertujuan untuk menguji apakah dalam model regresi variabel terikat dan variabel bebas keduanya mempunyai distribusi normal ataukah tidak. Model regresi yang baik adalah memiliki distribusi data normal atau mendekati normal. Dasar pengambilan keputusan dalam uji normalitas yakni jika nilai signifikansi lebih besar dari 0,05, nilai ini diambil pada hasil uji nirmalitas menggunakan SPSS versi 20. 


\section{Tabel Hasil Uji Normalitas}

$\begin{aligned} & \text { One-Sample } \\
& \text { Test }\end{aligned}$
\begin{tabular}{|ll|l|}
\hline & \multicolumn{2}{c|}{ Kolmogorov-Smirnov } \\
& & $\begin{array}{l}\text { Unstand } \\
\text { ardized } \\
\text { Residual }\end{array}$ \\
\hline $\mathrm{N}$ & 45 \\
Normal $\quad$ Mean & $0 \mathrm{E}-7$ \\
Parameters & Std. Deviation & 4,95471 \\
,b & 042 \\
Most & Absolute &, 162 \\
Extreme $\quad$ Positive &, 066 \\
Differences & Negative &,- 162 \\
Kolmogorov-Smirnov Z & 1,085 \\
Asymp. Sig. (2-tailed) &, 189 \\
\hline
\end{tabular}
a. Test distribution is Normal.
b. Calculated from data.

Dari tabel diatas didapatkan nilai residual sebesar 0,189 lebih besar dari 0,05 dari nilai sampel sebesar 45 yang berarti data yang sedang diuji berdistribusi normal.

Uji Multikolinearitas

Tabel Hasil Uji Multikolinearitas

\begin{tabular}{|ll|l|l|}
\hline \multicolumn{2}{|l|}{ Model } & \multicolumn{2}{|l|}{ Collinearity Statistics } \\
\cline { 2 - 3 } & Tolerance & VIF \\
\hline \multicolumn{2}{|c|}{ (Constant) } & & \\
1 & $x 1$ &, 727 & 1,375 \\
& $x 2$ &, 727 & 1,375 \\
\hline
\end{tabular}

Dari tabel diatas dapat disimpulkan bahwa semua variabel telah lolos dari uji multikolinearitas dengan penjabaran sebagai berikut :

a. Variabel $\mathrm{X}_{1}$ tidak terjadi multikolinearitas dikarenakan nilai VIF yang bernilai 1,375 lebih kecil dari 10,00, dan nilai Tolerance yang bernilai 0,727 lebih besar dari 0,10 .

b. Variabel $\mathrm{X}_{2}$ tidak terjadi multikolinearitas

dikarenakan nilai VIF yang bernilai 1,375 lebih kecil dari 10,00.dan nilai Tolerance yang bernilai 0,727 lebih besar dari 0,10 .

\section{Uji Heteroskedastisitas}

Uji heterokedastisitas bertujuan menguji apakah dalam model regresi terjadi ketidaksamaan variance dari residual satu pengamatan ke pengamatan yang lain. Ada beberapa cara yang dapat dilakukan untuk melakukan uji heteroskedastisitas, yaitu uji grafik plot, uji park, uji glejser, dan uji white. Pengujian pada penelitian ini menggunakan Grafik Plot antara nilai prediksi variabel dependen yaitu ZPRED dengan residualnya SRESID. Tidak terjadi heteroskedastisitas apabila tidak ada pola yang jelas, serta titik-titik menyebar di atas dan di bawah angka 0 pada sumbu Y. (Imam Ghozali, 2016 :61). Haslil uji heteroskedastisitas pada penelitian ini dapat dilihat pada gambar berikut:

\section{Hasil Uji Heteroskedastisitas}




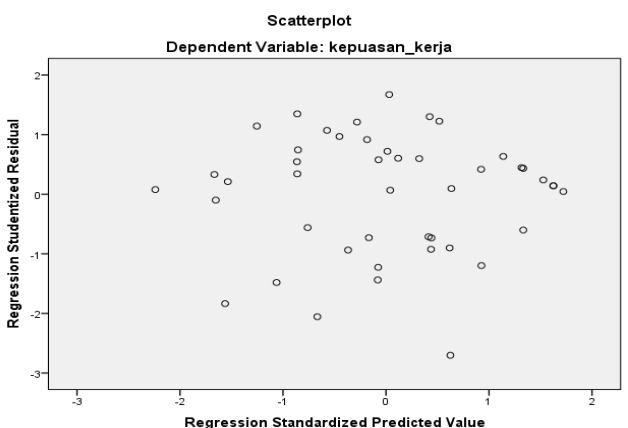

Dari gambar di atas dapat disimpulkan bahwa titik-titik menyebar dan tidak membentuk pola tertentu yang jelas. Sehingga tidak terjadi heteroskedastisitas.

\section{Analisa Kuantitatif}

\section{Analisa Linear Berganda}

Hasil pengujian analisis regresi linier bergandapada penelitian ini diadopsi dari tabel coefficients yang dapat dilihat pada tabel berikut ini.

\section{Tabel Coefficients}

\begin{tabular}{|c|l|l|l|}
\hline Model & \multicolumn{2}{|l|}{$\begin{array}{l}\text { Unstandardi } \\
\text { zed } \\
\text { Coefficients }\end{array}$} & $\begin{array}{l}\text { Standardized } \\
\text { Coefficients }\end{array}$ \\
\cline { 2 - 4 } & $\mathrm{B}$ & $\begin{array}{l}\text { Std. } \\
\text { Error }\end{array}$ & Beta \\
\hline $\begin{array}{l}\text { (Const } \\
\text { ant) } \\
\text { Kompe } \\
\text { nsasi } \\
\text { lingkun } \\
\text { gan_k } \\
\text { erja }\end{array}$ & 4,470 & 13,86 &, 185 \\
\hline
\end{tabular}

Dari tabel dapat ditarik persamaan regresinya sebagai berikut :

$\mathrm{Y}=4,227+0,470 \mathrm{X}_{1}+0,486 \mathrm{X}_{2}$

Keterangan :

1.Nilai konstanta sebesar 4,227 berarti apabila variabel kompensasi dan lingkungan kerja sama dengan nol (0), maka variabel kepuasan kerja bernilai 4,227 satuan.

2.Nilai koefisien regresi variabel kompensasi sebesar 0,470 berarti bahwa koefesien ini bernilai positif. peningkatan variabel kompensas $\left(\mathrm{X}_{1}\right)$ sebesar satu satuan maka kepuasan kerja $(\mathrm{Y})$ akan meningkatkan sebesar 0,470 satuan. Peningkatan variabel kompensasi berakibat meningkatnya pada variabel kepuasan kerja karyawan.

3.Nilai koefisien regresi variabel lingkungan kerja sebesar 0,486, berarti bahwa koefesien ini bernilai positif. Peningkatan variabel lingkungan kerja $\left(\mathrm{X}_{2}\right)$ sebesar satu satuan maka variabel kepuasan kerja (Y) akan meningkat sebesar 0,486 satuan. Kenaikan variabel lingkungan kerja berakibat kenaikan pada variabel kepuasan kerja karyawan

\section{Analisa Determinasi}

Koefisien determinasi dihitung dengan mengkuadratkan Koefisien Korelasi (R). Penggunakan R Square $\left(\mathrm{R}^{2}\right) \quad$ sering menimbulkan permasalahan, yaitu bahwa nilainya akan selalu meningkat dengan adanya penambahan variabel bebas dalam suatu model. Hal ini akan menimbulkan bias, karena jika ingin memperoleh model dengan $\mathrm{R}$ tinggi, oleh karena itu, banyak peneliti yang menyarankan untuk menggunakan Adjusted R Square. Interpretasinya sama dengan $\mathrm{R}$ Square, akan tetapi nilai Adjusted R Squaredapat naik atau turun dengan adanya penambahan variabel baru, tergantung dari korelasi antara variabel bebas tambahan tersebut dengan variabel terikatnya (Santoso, 
2010:89). Nilai Adjusted R Square dapat bernilai negatif, sehingga jika nilainya negatif, maka nilai tersebut dianggap 0 , atau variabel bebas sama sekali tidak mampu menjelaskan varians dari variabel terikatnya. Nilai koefisien determinasi dari variabel Pengembangan Karir terhadap Kinerja dapat dilihat pada tabel berikut ini :

\section{Tabel}

\section{Koefesien Determinasi}

\begin{tabular}{|l|l|l|l|l|}
\hline $\begin{array}{l}\text { Mo } \\
\text { del }\end{array}$ & $R$ & $\begin{array}{l}\text { R } \\
\text { Squar } \\
\text { e }\end{array}$ & $\begin{array}{l}\text { Adjusted } \\
\text { R Square }\end{array}$ & $\begin{array}{l}\text { Std. Error } \\
\text { of the } \\
\text { Estimate }\end{array}$ \\
\hline 1 &, 698 &, 487 &, 463 & 5,07131 \\
\hline
\end{tabular}

Berdasarkan tabel, terlihat nilai Adjusted R Squarevariabel independen, adalah sebesar 0,463. Berarti kemampuan variabel kompensasi dan lingkungan kerja dalam menjelaskan varians dari variabel kepuasan kerja adalah sebesar 46,3\%. Berarti terdapat $53,7 \%$ varians variabel kepuasan kerja yang dijelaskan oleh variabel lain.

\section{Pengujian Hipotesis}

\section{Uji t}

Uji $t$ digunakan untuk menguji apakah terdapat pengaruh yang signifikan secara individual dari variabel bebas terhadap variabel terikat. Uji $t$ digunakan untuk menjawab hipotesis pertama dan kedua. Hasil uji t dari penelitian ini dapat disajikan pada tabel berikut ini.

\section{Tabel Hasil Uji t}

\begin{tabular}{|ll|l|l|}
\hline \multicolumn{2}{|l|}{ Model } & T & Sig. \\
\hline \multicolumn{1}{|l|}{ (Constant) } &, 305 &, 762 \\
1 & x1 & 2,540 &, 015 \\
& x2 & 3,607 &, 001 \\
\hline
\end{tabular}

Dengan menggunakan tingkat signifikansi $0,05(\alpha=5 \%)$ dan $t$ tabel pada signifikansi 0,05 uji dua arah dengan derajat kebebasan df n-k-1 = $45-2-1=42$ (n adalah jumlah responden dan $\mathrm{k}$ adalah jumlah variabel bebas) dengan nilai $\mathrm{t}$ tabel sebesar 2,018 (lihat lampiran table t). Hasil uji t dapat dilihat pada output SPSS dari tabel 4.15. di atas diketahui sebagai berikut:

a.Variable kompensasi memiliki $\mathrm{t}$ hitung(2,540) $>\mathrm{t}$ tabel $(2,018)$ dan nilai sig perhitungan yang diperoleh adalah sebesar $0,015<0,05$, jadi $\mathrm{H}_{\mathrm{o}}$ ditolak $\mathrm{H}_{\mathrm{a}}$ diterima. Dengan demikian dapat disimpulkan bahwa kompensasi secara individual berpengaruh dan signifikan terhadap kepuasan kerja karyawan

b.Variable lingkungan kerja memiliki $\mathrm{t}$ hitung $(3,607)>\mathrm{t}$ tabel $(2,018)$ dan nilai sig perhitungan yang diperoleh adalah sebesar $0,001<0,05$ jadi $\mathrm{H}_{\mathrm{o}}$ ditolak $\mathrm{H}_{\mathrm{a}}$ diterima. Dengan demikian dapat disimpulkan bahwa lingkungan kerja secara individual berpengaruh dan signifikan terhadap kepuasan kerja karyawan

\section{Uji F}


Uji F dilakukan dengan melihat nilai $F$ hitung dan nilai sig. Uji $F$ digunakan untuk menjawab hipotesis ketiga. Tabel ANOVA dari output SPSS. Hasil pengujian disajikan pada tabel berikiut ini.

\section{Tabel}

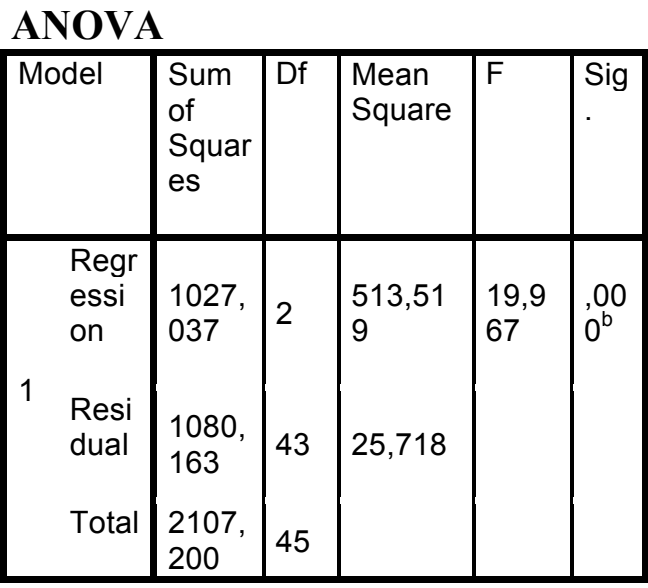

Dari tabel tersebut diketahui nilai $\mathrm{F}$ hitung 19,967 yang lebih besar dari nilai $F$ tabel sebesar 4,07 (lihat lampiran tabel F) dan nilai probabilitas yang dihasilkan dari perhitungan adalah $0,000^{\mathrm{b}}$ lebih kecil dari $\alpha(5 \%)$. Dengan demikian dapat disimpulkan variabel kompensasi dan lingkungan kerja secara bersamasama atau simultan berpengaruh dan signifikan terhadap kepuasan kerja karyawan .

\section{Pembahasan}

Dari pembahasan hasil penelitian di atas menunjukan bahwa kompensasi dan lingkungan kerja berpengaruh positif terhadap kepuasan kerja karyawan pada PT.Famili Raya Padang. Rincian pembahasan dapat dijelaskan sebagai berikut:

1. Pengaruh kompensasi Terhadap kepuasan kerja
Hasil penelitian menunjukan bahwa ada pengaruh positif antara variabel kompensasi terhadap kepuasan kerja karyawan pada PT.Famili Raya Padang. Dengan nilai koefesien regresi sebesar 2,540, kompensasi berpengaruh dan signifikan terhadap kepuasan kerja. Sehingga dapat disimpulkan bahwa kompensasi berpengaruh positif dan signifikan terhadap kepuasan kerja. . Penelitian ini sama dengan penelitian yang dilakukan oleh Siti Utari, yang menyatakan bahwa kompensasi berpengaruh positif dan signifikan terhadap kepuasan kerja karyawan

2. Pengaruh lingkungan kerja Terhadap kepuasan kerja

Hasil penelitian menunjukan bahwa ada pengaruh positif antara variabel lingkungan kerja terhadap kepuasan kerja karyawan pada PT.Famili Raya Padang . nilai sig $0,001<0,05$. sehingga dapat disimpulkan bahwa lingkungan kerja berpengaruh positif dan signifikan terhadap kepuasan kerja karyawan pada PT.Famili Raya Padang. Penelitian ini sejalan dengan penelitian yang dilakukan oleh Nuridha dkk, yang menyatakan bahwa lingkungan kerja berpengaruh positif dan signifikan terhadap kepuasan kerja karyawan. 
3. Pengaruh kompensasi Dan lingkungan kerja Terhadap kepuasan kerja

Diketahui berdasarkan hasil uji $\mathrm{F}$ bahwa variabel kompensasi dan lingkungan kerja bersama-sama memiliki pengaruh signifikan terhadap kepuasan kerja karyawan pada PT.Famili Raya Padang, hal ini terlihat dari nilai $\mathrm{F}$ hitung 19,967 $>\mathrm{F}$ tabel 4,07 dan nilai sig $0,000<0,05$. Penelitian ini sejalan dengan penelitian yang dilakukan oleh Ida Bagus,Alit dkk, yang menyatakan bahwa kompensasi dan lingkungan kerja berpengaruh positif dan signifikan terhadap kepuasan kerja karyawan.

\section{KESIMPULAN DAN SARAN}

\section{Kesimpulan}

Berdasarkan hasil analisis dan pembahasan mengenai pengaruh kompensasi $\left(\mathrm{X}_{1}\right)$ dan lingkungan $\operatorname{kerja}\left(\mathrm{X}_{2}\right)$ terhadap kepuasan kerja(Y), maka dapat ditarik kesimpulan sebagai berikut :

1. Hasil penelitian menunjukan bahwa ada pengaruh positif antara variabel kompensasi terhadap kepuasan kerja karyawan pada PT.Famili Raya Padang. Dengan nilai koefesien regresi sebesar 2,540, kompensasi berpengaruh dan signifikan terhadap kepuasan kerja. Sehingga dapat disimpulkan bahwa kompensasi berpengaruh positif dan signifikan terhadap kepuasan kerja
2. Hasil penelitian menunjukan bahwa ada pengaruh positif antara variabel lingkungan kerja terhadap kepuasan kerja karyawan pada PT.Famili Raya Padang. nilai sig $0,001<0,05$. sehingga dapat disimpulkan bahwa lingkungan kerja berpengaruh positif dan signifikan terhadap kepuasan kerja karyawan pada PT.Famili Raya Padang .

3.Diketahui berdasarkan hasil uji F bahwa variabel kompensasi dan lingkungan kerja bersama-sama memiliki pengaruh signifikan terhadap kepuasan kerja karyawan pada PT.Famili Raya Padang hal ini terlihat dari nilai $\mathrm{F}$ hitung 19,967 > F tabel 4,07 dan nilai sig $0,000<0,05$.

\section{Saran}

Berdasarkan kesimpulan di atas, dapat dikemukakan beberapa saran yang diharapkan dapat bermanfaat bagi perusahaan atau pihak lain yang berkepentingan. Adapun saran yang diberikan, antara lain :

1. Bagi perusahaan

Dari hasil penelitiaan penulis tentang kompensasi dan lingkungan kerja terhadap kepuasan kerja karyawan, dimana hasil penelitiaan mendapatkan kesimpulan bahwa kompensasi dan lingkungan kerja sangat berpengaruh sekali terhadap kepuasan kerja karyawan di PT.Famili Raya Padang.

2. Bagi akademik 
Diharapkan bagi peneliti selanjutnya yang akan meneliti tentang Pengaruh Kompensasi dan Lingkungan Kerja terhadap Kepuasan Kinerja Karyawan Pada PT.Famili Raya Padang atau menambah variabel lainnya sebagai panduan yang akan diteliti.

3.Bagi penulis

Dalam penelitian ini penulis menyadari banyaknya kekurangan dalam penyelesaian skripsi ini mengenai kompensasi dan Lingkungan Kerja Terhadap Kepuasan Kerja Karyawan Pada PT.Famili Raya Padang.

4.Bagi pihak lain

Diharapkan bagi peneliti selanjutnya, agar dapat menjadi panduan atau referensi tambahan terutama bagi peneliti yang mengambil penelitiaan ini yaitu mengenai Pengaruh Kompensasi Dan Lingkungan Kerja Terhadap Kepuasan Kerja Karyawan Pada PT.Famili Raya Padang.

\section{DAFTAR PUSTAKA}

\section{Buku}

Agussalim

Manguluang.2010.Metedologi

Penelitian. Padang: Ekasakti Press.

Agussalim.2015.Statistik

Dasar.Cetakan I.Padang : Ekasakti Press.

Akbar.2012.Pengaruh Kompensasi Motivasi Kerja Dan Kepuasan Kerja Terhadap Kinerja Karyawan (Studi Pizza Hut Kota Padang).
Anggiawan,Koko

Happy.2015.Pengaruh insentif dan motivasi kerja terhadap kinerja karyawan (studi kasus pada Cv. Suka Alam(Kaliwatu Rafting) Kota Btua, Jawa Timur).

Ardana.2011.Manajemen Sumber Daya Manusia.Denpasar : Graha Ilmu.

Arikunto.2010.Prosedur Penelitian Suatu Pendekatan Praktik.Edisi Revisi 2010.Jakarta : Rineka Cipta.

Badriyah,M.2015.Manajemen

Sumber Daya Manusia,Cetakan 1.Bandung : CV Pustaka Setia.

Bejo,Siswanto.2010.Manajemen Tenaga Kerja Indonesia Pendekatan Administrative Dan Operasional, Jakarta : Bumi Aksara.

Dessler.2011.Manajemen Sumber Daya Manusia.Penerbit Indeks,Jakarta.

Edy,Sutrisno2011.Manajemen

Sumber Daya Manusia.Jakarta : Kencana Prenada Media Group.

Fauzan, Usman.2014.Pengaruh Kompensasi Terhadap Kinerja Karyawan Pada PT.Trakindo Utama Samarinda.

Ghozali.2011.Aplikasi Analisis Multivariate Dengan Program SPSS. Semarang : Badan Penerbit Universitas Diponegoro.

Gujarati.2012.Dasar-dasar

Ekometrika. Jakarta : Salemba Empat.

Hanafiah.2012.Konsep Strategi Pembelajaran.Bandung.Refika Aditama. 
Hariandjo.2010.Manajemen Sumber Daya Manusia.Jakarta

PT.Gramedia Widiasarana Indonesia.

Hasibuan.2010.Manajemen Sumber Daya Manusia.Jakarta : PT.Bumi Aksara.

Ida Bagus, Alit Ksama Putra.2016.Pengaruh Kompensasi Dan Kepuasan Kerja Terhadap Kinerja Karyawan Pada Pt.Kubu Jati Singorojo Bali.

Ilah,Dede

Kurnia.2017.Pengaruh Kepuasan Kerja Terhadap Disiplin Kerja Dan Komitmen Organisasional ( Studi pada karyawan PT.PLN (PERSERO) Distribusi Jawa Timur Area Malang).

Indrawati, Ayu Desi.2013.Pengaruh Kepuasan Kerja Terhadap Kinerja Karyawan Dan Kepuasan Pelanggan Pada Rumah Sakit Swasta Di Kota Denpasar.

Kartono.2011.Pemimpin Dan Kepemimpinan.Jakarta : Pt.Raja Wali Grafindo Persada.

Kreitner dan Knicki.2014.Perilaku Organisasi. Jakarta : Salemba Empat.

Martinus,Erik.2016.Pengaruh Kompensasi Dan Motivasi Kerja Terhadap Kinerja Karyawan Pada Pt.Devina Surabaya.

Nightyas, Nuridho

Citra.2017.Pengaruh Pelatihan dan Lingkungan Kerja Terhadap Kinerja Karyawan Dengan Kepuasan Kerja Sebagai Variabel Intervering.
Nitisemito.2010.Manajemen

Personalia.Ghalia Indonesia,Jakarta.

Noe, Aulia dan

Troena.2013:4.Pengaruh

Kompensasi Finansial dan Non Finansial Terhadap Motivasi Kerja Karyawan Universitas Brawijoyo Hotel Kota Malang (Skripsi).

Panggabean,Subekhi.2012.Penganta $r$ Manajemen Sumber Daya Manusia. Prestasi Pustaka Jakarta.Jakarta.

Rachmawati,Fitri.2014.Pengaruh Lingkungan Kerja, Keterampilan Kerja Dan Jenjang Karir Terhadap Kinerja Karyawan.

Robins.2010.Manjemen.(Edisi Kesepuluh).Jakarta : Erlangga.

Sari, Elvi Liana.2015.Pengaruh Pemberian Kompensasi Terhadap Produktivitas Kerja Karyawan Pada Pt.Ryan Jaya Persada.

Sedarmayanti,Wulan.2010.Analisis

Pengaruh Motivasi Kerja Dan Lingkungan Kerja Terhadap Kinerja Karyawan (Studi Pada Dinas Perindustrian Dan Pelanggan Kota Semarang.Skripsi Semarang : Fakultas Ekonomi Universitas Diponegoro.

Sedarmayanti.2010.Manajemen Sumber Daya Manusia. Reformasi Birokrasi Dan Manajemen Pegawai Negri Sipil Bandung : PT.Refka Aditama.

Setiawan,Kiki

Cahayo.2015.Pengaruh motivasi kerja terhadap kinerja karyawan level pelaksanaan (studi kasus pada divisi operasi PT. Pusri Palembang). 
$\begin{array}{lr}\text { Sewatno } & \text { dan } \\ \text { Priansa,D.2011.Manajemen } & \text { SDM } \\ \text { Dalam Organisasi Publik } & \text { Dan } \\ \text { Bisnis. Bandung : Alfabetha. } & \end{array}$

Singgih,Santoso.2012.SPSS Versi 11.5 Cetakan Kedua Jakarta : Gramedia.

Simajuntak.2011.Manajemen Dan Evaluasi Kinerja.Jakarta Universitas Indonesia.

Simamora,Henry.2012.Manajemen

Sumber Daya

Manusia.Gramedia,Jakarta.

Soyfan,Dhiana

Khairani.2013.Pengaruh Lingkungan

Kerja Terhadap Kinerja Pegawai BAPPEDA.

Sugiyono.2013.Metode Penelitian Manajemen.Bandung : Alfabeta.

Sugiyono.2015. Metode Penelitian Pendidikan: Pendekatan Kuantitatif, Kualitatif, dan $R \& D$. Bandung: Alfabeta

Sunyoto,D.2012.Manajemen Sumber Daya Manusia.Yogyakarta : CAPS.

Supatmi,Mamik Eko.2010.Pengaruh Pelatihan, Kompensasi Terhadap Kepuasan Kerja Karyawan Dan Kinerja Karyawan.

Sutrisno Hadi.2016.Statiska.Cetakan III .Yogyakarta : Pustaka Pelajar.

Untari,Siti.2014. Pengaruh Kompetensi Dan Lingkungan Kerja Terhadap Kinerja Karyawan pada CV Buana Mas Jaya Surabaya.

Wibowo.2010.Manajemen Kinerja.Jakarta : Raja Wali.Press
Yuniastuti,Rina Milyanti.2011:199210.Pengaruh Kepuasan Kerja Terhadap Prestasi Kerja Karyawan Pada CV.Organik Agro System Di Bandar Lampung Vol : No :1 Tahun 2010.

Yuniati,Tri.2016. Pengaruh Kepuasan Kerja Terhadap Kinerja Karyawan Dengan Komitmen Organisasional Sebagai Variabel Intervering Vol :5 No:1 Januari 2016. 